\section{Indonesia struggles to control bird flu outbreak}

\begin{abstract}
As officials in Washington discuss how to tackle outbreaks of bird flu more effectively (see page 927), an outbreak in humans continues in Asia. Declan Butler assesses the situation in Indonesia, and finds out how likely it is that the virus might evolve into a pandemic strain.
\end{abstract}

How worrying is the

Indonesian outbreak?

Previous human outbreaks

have largely been in quite

remote areas, but this one is

centred on Jakarta, one of the

world's largest conurbations

and home to some 21 million

people. Moreover, the

country's population of 240

million looks after 1.3 billion

chickens, many of which

live among the 30 million

backyard farms. These are

spread across some 6,000

inhabited islands, making it

difficult to track and control

cases. Most of the cases so far

have arisen on Java, home to

half of Indonesia's population.

It is also unclear when or if the outbreak will end. Avian

flu is now endemic in

Indonesian poultry, in part

because the government failed

to cull birds when the virus first appeared.

What is so bad about the H5N1 strain of avian flu virus?

When scientists sequenced the genome of the flu strain that caused the devastating 1918 pandemic (see Nature 437, 794-795; 2005), they concluded that it probably arose from an avian flu that jumped directly to humans.

The team identified 25-30 amino-acid mutations in 1918 flu that seem to account for its virulence. Initial analysis of $\mathrm{H} 5 \mathrm{~N} 1$, which has killed 65 people in Asia so far, suggests that it already has some of these mutations. The fear is that if it accumulates more, it could acquire the ability to spread readily between humans. Each new human case gives the virus a chance to mutate and gain this ability.

How many people have the virus? The media, the Indonesian government and the World Health Organization (WHO) all give conflicting numbers. This is partly declares cases immediately, whereas the WHO does not count cases until it has checked them in its own labs. The best current estimate, based on tests done by the Ministry of Health and the US Naval Medical Research Unit
Number 2 (NAMRU-2) in Jakarta, is seven confirmed cases and two probable cases. Six of these nine individuals have died. There are also about 80 suspected cases, but most will

How wellequipped is Indonesia to detect and treat cases quickly?

Outbreak investigation staff are stretched but coping, according to Steven Bjorge at the WHO's Jakarta office. Others are less sanguine. "One just has to look at the current polio, measles and dengue epidemics in Indonesia to probably prove not to be $\mathrm{H} 5 \mathrm{~N} 1$.

\section{IMAGE UNAVAILABLE FOR COPYRIGHT REASONS}

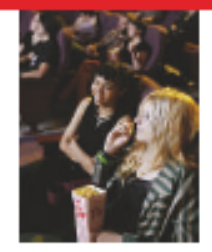

SCENTISTS DANGLEBAIT

FOR SCREENWRITERS

Film summit puts a

spotlight on untold stories

from thelab.

www.nature.com/news

realize that the public-health system is having trouble coping with preventable diseases, so I don't have a lot of faith," says one scientist involved in monitoring the outbreak.

But other countries are helping out. Until 1999 , Indonesia had virtually no flusurveillance capacity. Since then, NAMRU-2, helped by the US Centers for Disease Control and Prevention in Atlanta, Georgia, has been working with the country's authorities to strengthen their ability to monitor and diagnose avian flu (C. G. Beckett et al. Clin. Infect. Dis. 39, 443-449; 2004). Over the past few weeks, teams have been sent to areas with poultry outbreaks to look for suspected human cases. Teams of foreign scientists, and aid, are also converging on the country.

Is the virus passing between people? Probably, but in only a very limited way. Most cases have been spread out but there have been some family clusters. In July, an eightyear-old became sick, followed by her sister and father. On 10 September, a 37-year-old woman died in Jakarta, then her nine-yearold nephew contracted the virus. And the most recent cases - four- and five-year-old boys - are the nephews of a 20-year-old patient from Bandar Lampung in Sumatra.

But nailing down human-to-human transmission is difficult. Researchers have to work out how the first case got infected from poultry, then rule out the possibility that the other family members did not catch the virus in the same way. Most of the time, the inquiry gets nowhere. "We have no firm evidence of human-to-human transmission within a family, although sometimes it is difficult to exclude it," says Bjorge.

Has thevirus mutated to make it more adapted to humans?

Not so far. "Sequences of recent human

"We have no firm evidence of human-tohuman transmission." isolates are very similar to previous ones in Indonesia," says Masato Tashiro, a virologist at the National Institute of Infectious Diseases in Tokyo,

which sent a team to Indonesia last week.

What are scientists worried about now? Vietnam is bracing itselffor an expected further wave of cases, as the colder temperatures during the winter months from November to February are conducive to transmission of the virus. Meanwhile, Europe is on the alert after suspected outbreaks were detected in poultry last weekend. If confirmed, they would add to fears that birds migrating from China and Russia this autumn may extend the geographical spread of $\mathrm{H} 5 \mathrm{~N} 1$. 